\title{
THE ACID-BASE BALANCE OF PREMATURE INFANTS ${ }^{1}$
}

\author{
BY W. STERRY BRANNING \\ (From the Departments of Biochemistry and Pediatrics, Duke University School of Medicine, \\ Durham, North Carolina)
}

(Received for publication September 24, 1941)

The acid-base balance of young children is known to be easily upset $(1,2)$ and that of fullterm new-born infants changes with slight variations in diet $(3,4)$. Premature infants are considered to be even more labile, but data are few. The symptoms of acidosis in prematures, such as hyperpnea, etc., may resemble those of older children, but often the condition may not be recognized clinically because sluggishness and refusal of feedings are the only signs. However, only those displaying hyperpnea were classified as acidotic for purposes of comparison in this paper. In order to obtain more data and to investigate the cause of their frequent acidosis, the acid-base balance was studied in seventeen premature infants whose birth weight was less than 2250 grams. Clinical aspects of these cases are discussed elsewhere (5).

\section{MATERIAL AND METHODS}

Alternate patients were fed dilute Olac or equal parts of evaporated milk and water with the addition of $71 / 2$ per cent cane sugar in amounts supplying 120 calories per kilo per day. All patients received $25 \mathrm{mgm}$. ascorbic acid daily after the thirteenth day, and 10 drops of oleum percomorphum daily after the twentieth day of life. Patients with clinical signs of acidosis were treated with M/6 sodium lactate parenterally, 60 cc. per kilo body weight.

Blood was drawn under oil with heparin as anticoagulant. Single specimens of urine were taken in test tubes; twenty-four-hour specimens were collected from males to whom funnels were strapped with tubing extending to urine receptacles containing toluene. In normal infants blood was drawn halfway through the twentyfour-hour urine collection.

Total base and chlorides of urine and blood were determined by electrodialysis (6). Formol titration of urinary cation mixture measured the ammonia. These results were checked by the method of Folin and Bell (6b).

Blood $\mathrm{pH}$ was measured in glass micro-electrodes, and the results were corrected by $+0.05 \mathrm{pH}$ to compensate

1 Presented in part by title at the meeting of the American Society for Clinical Investigation in Atlantic City, New Jersey, May 6, 1941. for the immediate acid change (7). Urine $\mathrm{pH}$ was measured with glass macro-electrodes.

Carbon dioxide content of plasma was determined in the Van Slyke manometric apparatus (8). Phosphorus in the blood was determined by the method of Kuttner and Lichtenstein (9), and in urine by that of Youngburg and Youngburg (10). Plasma proteins were determined by the direct nesslerization method of Wong (11) and read in the Evelyn photoelectric colorimeter.

Total organic acids in plasma were calculated by subtraction of the total anion content from the total base, expressed as milliequivalents per liter. For this purpose, sulfates were assumed to account for two milliequivalents per liter. Total organic acids in urine were determined by the method of Greenwald (12) adapted for titration with the glass electrode. Lactic acid in blood was determined by the method of Elgart and Harris (13), and in urine by that of Friedemann, Cotonio and Shaffer (14).

\section{RESULTS AND DISCUSSION}

Table I lists the findings on the blood of fifteen premature infants when all clinical signs indicated

TABLE I

Premature infants in good condition

Determinations on blood plasma in m.eq. per liter

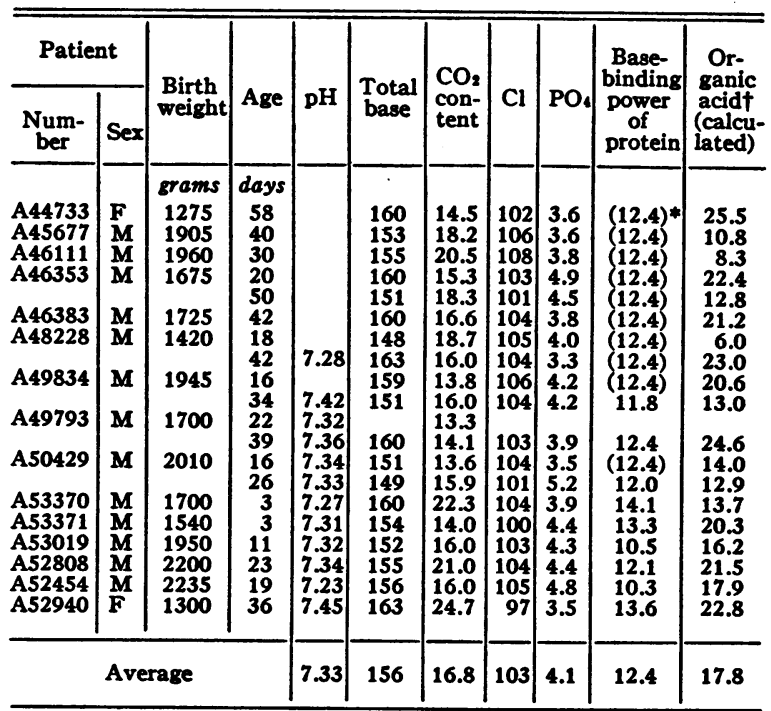

* Figuires in parentheses are averages discussed in text. $\dagger_{\mathrm{SO}_{4}}$ is assumed to be $2 \mathrm{~m}$.eq. per liter of plasma for calculation of organic acid content. 
a satisfactory condition. All of them had total base and chlorides within the limits of normal. Plasma phosphates were high, as is usual in infants. Prematures with clinical evidence of acidosis (hyperpnea, etc.) were also normal in these respects (Table II).

TABLE II

Clinically acidotic prematures

Determinations on blood plasma in m. eq. per liter

\begin{tabular}{|c|c|c|c|c|c|c|c|c|c|}
\hline \multicolumn{2}{|c|}{ Patient } & \multirow{2}{*}{ Age } & \multirow{2}{*}{ pH } & \multirow{2}{*}{$\begin{array}{l}\text { Total } \\
\text { base }\end{array}$} & \multirow{2}{*}{$\begin{array}{l}\mathrm{CO}_{2} \\
\text { con- } \\
\text { tent }\end{array}$} & \multirow{2}{*}{$\mathrm{Cl}$} & \multirow{2}{*}{ PO. } & \multirow{2}{*}{$\begin{array}{l}\text { Base- } \\
\text { binding } \\
\text { power of } \\
\text { protein }\end{array}$} & \multirow{2}{*}{$\begin{array}{l}\text { Organic } \\
\text { acid } \\
\text { (caleu- } \\
\text { lated)* }\end{array}$} \\
\hline Number & Sex & & & & & & & & \\
\hline $\begin{array}{l}\text { A44733 } \\
\text { A46353 } \\
\text { A46383 } \\
\text { A52808 } \\
\text { A52454 } \\
\text { A45227 } \\
\text { A52425 }\end{array}$ & $\begin{array}{l}\mathbf{F} \\
\mathbf{M} \\
\mathbf{M} \\
\mathbf{M} \\
\mathbf{M} \\
\mathbf{M} \\
\mathbf{F}\end{array}$ & $\begin{array}{c}\text { days } \\
62 \\
44 \\
37 \\
12 \\
14 \\
13 \\
45\end{array}$ & $\begin{array}{l}7.31 \\
7.26 \\
7.24\end{array}$ & \begin{tabular}{|l}
150 \\
154 \\
155 \\
149 \\
160 \\
160
\end{tabular} & $\begin{array}{l}9 \\
11 \\
13.5 \\
16 \\
11 \\
10 \\
14.1\end{array}$ & $\begin{array}{r}99 \\
96 \\
96 \\
103 \\
107 \\
108 \\
103\end{array}$ & $\begin{array}{l}4.6 \\
3.7 \\
4.2 \\
4.8 \\
5.0 \\
3.5\end{array}$ & $\begin{array}{c}(12.4) \dagger \\
(12.4) \\
(12.4) \\
12.9 \\
12.6 \\
(12.4) \\
13.6\end{array}$ & $\begin{array}{l}23 \\
28 \\
16.5 \\
11.6 \\
22.6 \\
23.7\end{array}$ \\
\hline
\end{tabular}

* $\mathrm{SO}_{4}$ is again assumed to be 2 m.eq. per liter.

$\dagger$ Figures in parentheses are averages discussed in text.

The carbon dioxide content of the plasma was uniformly low. Patient A52940, who had a carbon dioxide content of 24.7 milliequivalents per liter, had received $4.0 \mathrm{cc}$. of 1.0 molar sodium lactate orally every eight hours for four days preceding the determinations. The blood $\mathrm{pH}$ roughly parallels the carbon dioxide content. Hyperpneic prematures had slightly lower levels, but the distinction was not sharp. The highest carbon dioxide content of the acidotic group, 16.0 milliequivalents per liter, was well above the lowest in the thriving group, yet the latter progressed satisfactorily without respiratory or feeding irregularity, and without prophylaxis against acidosis.

The plasma proteins of the last nine infants in the normal series were determined simultaneously with the other tests. For the first six, a figure of 12.4 milliequivalents per liter was assumed, this being the average value from more than thirty determinations on the later infants, and on other prematures not in the series. Patients A46111 and A48228 were slightly edematous at the time of sampling, so that this figure is probably too high in their cases. There was no remarkable difference between the well and acidotic infants on this score.

The calculated organic acid contents of the plasma indicated an amount two to four times the amount considered normal for older patients. They varied inversely as the carbon dioxide content, and were only slightly higher in the acidotic than in the clinically well infants. Figure 1 is il-

TABLE III

Premature infants in good condition

Determinations on urine in m.eq. per liter

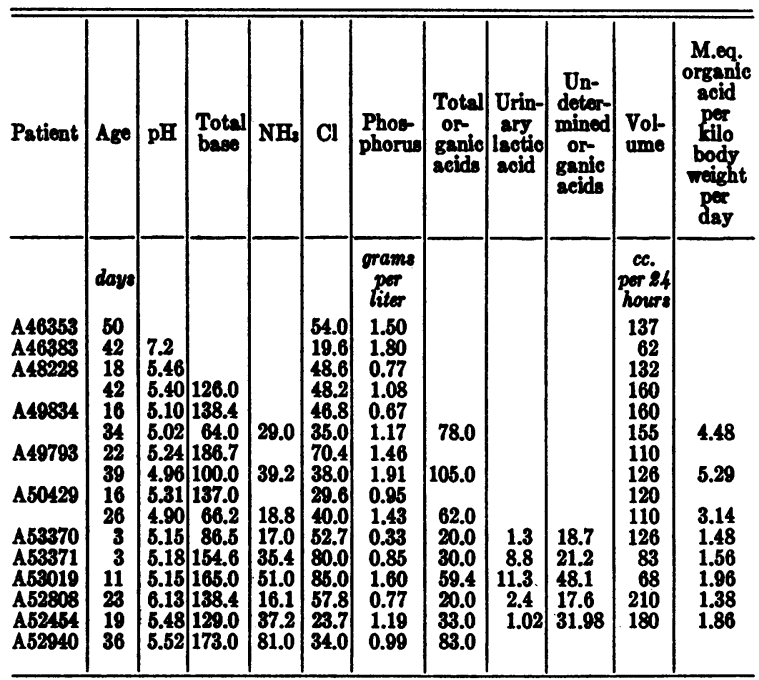

TABLE IV

Clinically acidotic prematures

Determinations on urine in m.eq. per liter

\begin{tabular}{|c|c|c|c|c|c|c|c|c|}
\hline Patient & Age & pH & $\begin{array}{l}\text { Total } \\
\text { base }\end{array}$ & $\mathrm{NH}_{2}$ & $\mathrm{Cl}$ & $\begin{array}{l}\text { Phos- } \\
\text { phorus }\end{array}$ & $\begin{array}{l}\text { Or- } \\
\text { ganic } \\
\text { acids }\end{array}$ & $\begin{array}{l}\text { Lac- } \\
\text { tic } \\
\text { acid }\end{array}$ \\
\hline $\begin{array}{l}\text { A44733* } \\
\text { After } 120 \\
\text { cc. } 1 / 6 M \\
\text { Na Lactate }\end{array}$ & $\begin{array}{c}\text { days } \\
62\end{array}$ & $\begin{array}{r}5.61 \\
5.52 \\
\end{array}$ & & & $\begin{array}{l}51 \\
86\end{array}$ & $\begin{array}{c}\text { grams } \\
\text { per liter } \\
0.48 \\
\\
1.15\end{array}$ & & \\
\hline $\begin{array}{l}\text { A46353 } \\
\text { After } 105 \\
\text { cc. 1/6 M } \\
\text { Na Lactate }\end{array}$ & 44 & & & & $\begin{array}{l}46 \\
53 \\
\end{array}$ & $\begin{array}{l}0.62 \\
1.10 \\
\end{array}$ & & \\
\hline $\begin{array}{l}\text { A46383 } \\
\text { After } 120 \\
\text { cc. 1/6 M } \\
\text { Na Lactate }\end{array}$ & 37 & $\begin{array}{l}5.28 \\
4.89\end{array}$ & & & $\begin{array}{l}26 \\
29\end{array}$ & $\begin{array}{l}0.70 \\
0.91\end{array}$ & & \\
\hline $\begin{array}{l}\text { A52808 } \\
\text { After } 75 \\
\text { cc. 1/6 M } \\
\text { Na Lactate }\end{array}$ & 12 & $\begin{array}{r}5.30 \\
4.94 \\
\end{array}$ & $\begin{array}{r}90 \\
184 \\
\end{array}$ & $\begin{array}{l}37 \\
86 \\
\end{array}$ & $\begin{array}{l}58 \\
44 \\
\end{array}$ & $\begin{array}{l}0.70 \\
2.00 \\
\end{array}$ & $\begin{array}{l}22.0 \\
50.0 \\
\end{array}$ & $\begin{array}{l}2.1 \\
5.4 \\
\end{array}$ \\
\hline $\begin{array}{l}\text { A52454 } \\
\text { After } 140 \\
\text { cc. 1/6 M } \\
\text { Na Lactate }\end{array}$ & 14 & $\begin{array}{l}5.20 \\
4.90\end{array}$ & $\begin{array}{l}135 \\
185\end{array}$ & $\begin{array}{l}34 \\
59\end{array}$ & $\begin{array}{l}62 \\
39\end{array}$ & $\begin{array}{l}1.23 \\
1.14\end{array}$ & $\begin{array}{l}32 \\
97\end{array}$ & $\begin{array}{r}11.0 \\
72.0\end{array}$ \\
\hline A45227 & 13 & 5.6 & & & 34 & 0.98 & & \\
\hline $\begin{array}{c}\text { A52425 } \\
\text { After } 60 \\
\text { cc. } 1 / 6 M \\
\text { Na Lactate }\end{array}$ & 45 & $\begin{array}{l}5.32 \\
4.89\end{array}$ & $\begin{array}{l}221.7 \\
232.6\end{array}$ & $\begin{array}{l}107 \\
122\end{array}$ & $\begin{array}{l}64.2 \\
38.4\end{array}$ & $\begin{array}{l}2.50 \\
2.56\end{array}$ & $\begin{array}{l}100.0 \\
116.0\end{array}$ & \\
\hline
\end{tabular}

* Died three days after this determination. This was the only infant in the series who did not recover promptly. 


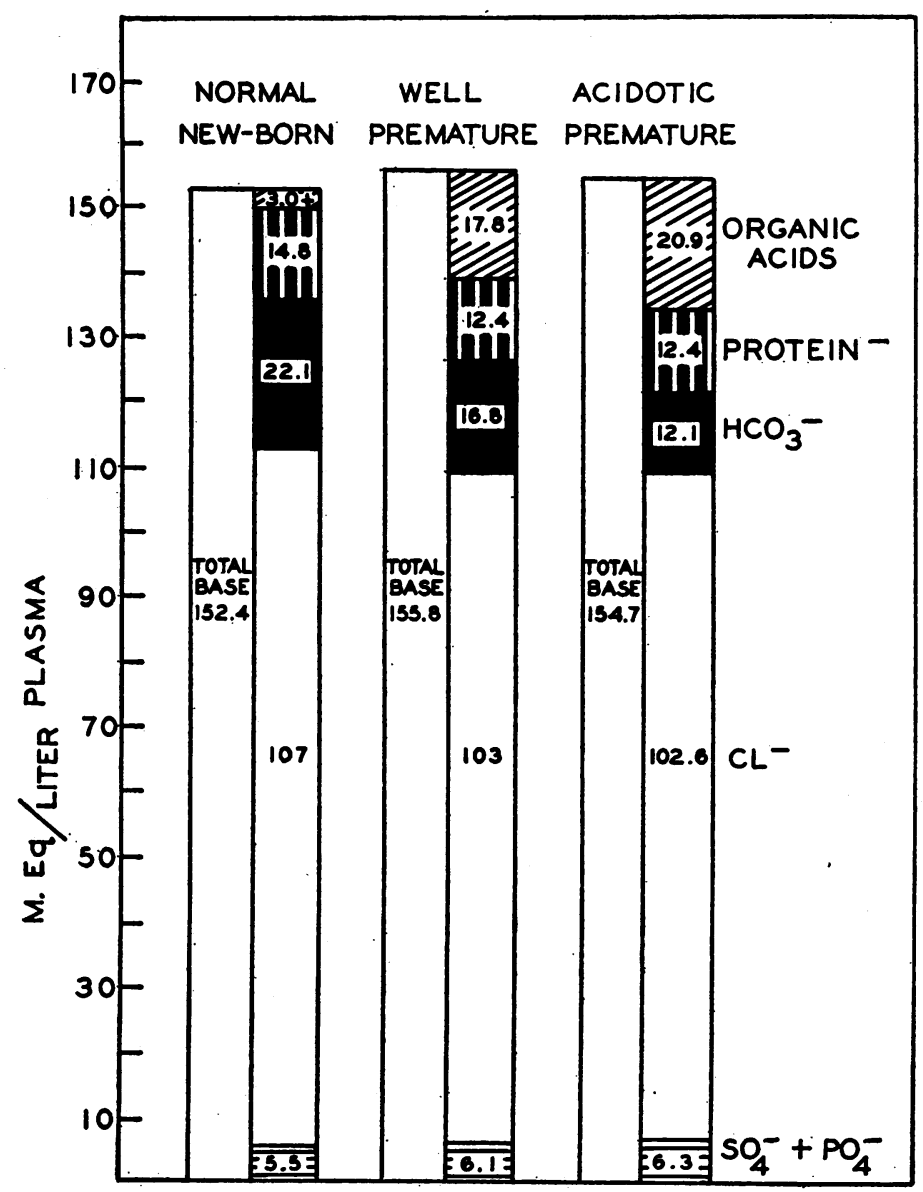

Fig. 1. Diagram Compares Average Figures for Total Base and Various Anions of Plasma of Normal New-born Infants, 15 Prematures Who Were Well Clinically, and 6 Prematures in ACIDOSIS (HyPERPNEIC)

Figures for normal new-born infants were taken from Marples and Lippard (3) whose organic acid estimation is probably low.

lustrative of the anion relations in the blood of full-term new-born infants in comparison with well and acidotic prematures.

All twenty-four-hour urine specimens were remarkably acid in spite of unavoidable loss of carbonic acid (Table III). Total base, ammonia, chloride and phosphorus followed no pattern, but it is worthy of notice that less fixed base is replaced by ammonia than might be expected in such acid urine.

The high calculated values for plasma organic acids are supported by the excretion of two to five times the normal adult amount per kilo body weight $(12,15)$. Added interest is warranted by the absence of the usual ketone bodies from the blood and urine of every infant studied.

When discovered in hyperpnea, an infant was strapped for a single specimen, and blood for determinations was drawn. As soon as the patient voided, $M / 6$ sodium lactate was given and the patient was strapped for a second specimen. The urine of the prematures in clinical acidosis (Table IV) was not as acid as expected, and it is remarkable that, after receiving the sodium lactate, the urine became more acid than before. Likewise, ammonia excretion increased proportionately, and the amount of phosphates was doubled. Because lactate was used therapeutically, lactic acid 
excretion was measured on some of the normal and acidotic infants. In the normal infants, it was usually low, and amounted at most to 20 per cent of the urinary organic acids in one case. Twenty normal prematures were found to have blood lactic acids varying from 2.7 to 4.2 milliequivalents per liter, with an average of 3.5 milliequivalents per liter. The increased excretion of organic acids after therapy is accounted for largely, though not entirely, by lactate. Sodium salts of certain organic acids received by infants are known to be excreted unchanged $(16,17)$. Such is probably the case here, but since the carbon dioxide content of plasma of these infants rises, and since weight gain is accelerated for the few days following therapy, a portion of the dose may be considered metabolized and its cations used to balance other anions for storage or excretion.

While this study was in progress, work was published on the presence of abnormal products of the metabolism of tyrosine and phenylalanine in the urine of premature infants who had received no ascorbic acid $(18,19)$. All the patients except A53370, A53371, and A53019 had been given 25 mgm. of ascorbic acid daily before determinations were done, beginning on the fourteenth day of life. Determinations were done on the urine of the last four patients, and on three other prematures not in this series, but no excretion of total hydroxy phenyl compounds was found to be greater than $64 \mathrm{mgm}$. per twenty-four hours, expressed as tyrosine (20).

The low plasma proteins found in these infants are probably part of the inefficiency evidenced in prematures by their well-known iron deficiency and their difficulty in the production of hemoglobin. In this connection, the excretion of less acid urines during acidosis than after therapy with fixed base brings into question the sufficiency of the premature kidney. Temporary functional renal insufficiency has been reported in cases of diabetic acidosis (21) in which azotemia associated with reduced renal clearance was rectified by restoration of normal acid-base and electrolyte balances. In premature infants the renal insufficiency is probably functional as well as due to immaturity, since after therapy they excrete not only a more acid urine, but a higher proportion of ammonia for the neutralization of urinary acids.
Urea clearance and blood nonprotein nitrogen studies would help clear up this point.

The addition of small amounts of fixed base to their feedings has been shown to benefit full-term new-born infants $(4,22)$. This is true also of prematures, but an increased supply of base seems only to facilitate the work of the kidney, not to correct the metabolic defect. At present an investigation is in progress in this laboratory to single out the particular organic acids involved. It is hoped that this study may indicate whether the entire metabolism of the premature is inefficient or whether some particular oxidative mechanism is at fault.

\section{SUMMARY AND CONCLUSIONS}

1. The acid-base balance of seventeen premature infants has been studied.

2. The plasma content of organic acids of premature infants is two to three times as great as that of the full-term infant and the adult. Ketone bodies are not responsible for this excess of organic acids.

3. Premature infants excrete two to five times the normal adult amount of organic acid per kilo body weight per day.

4. Although the electrolyte pattern in the plasma differs greatly from that of the term infant, it is fairly rigidly maintained and is not appreciably altered by alkali therapy.

5. The organic acid and carbon dioxide contents of plasma of clinically acidotic (hyperpneic) premature infants differ little from those of infants who are clinically thriving. This is taken to indicate that the premature infant is always on the borderline of acidosis.

\section{BIBLIOGRAPHY}

1. Gamble, J. L., Ross, G. S., and Tisdall, F. F., Studies of tetany; the effect of calcium chloride on the acid-base metabolism of infants. Am. J. Dis. Child., 1923, 25, 455.

2. Wilson, J. R., Levine, S. Z, and Rivkin, H., The respiratory metabolism in infancy and childhood; ketosis and the respiratory exchange in children. Am. J. Dis. Child., 1926, 31, 335.

3. Marples, E., and Lippard, V. W., Acid-base balance of new-born infants; influence of cow's milk on the acid base balance of the blood of new-born infants. Am. J. Dis. Child., 1933, 45, 294. 
4. Lippard, V. W., and Marples, E., Acid-base balance of new-born infants; effect of ingestion of alkali on acid-base balance of new-born infants. Am. J. Dis. Child., 1933, 46, 495.

5. McBryde, A., and Branning, W. S., Acidosis in premature infants; a clinical report. (In preparation.)

6a. Joseph, N. R., and Stadie, W. C., The simultaneous determination of total base and chloride on the same sample of serum by electrodialysis. J. Biol. Chem., 1938, 125, 795.

b. Folin, O., and Bell, R. D., Applications of a new reagent for the separation of ammonia; the colorimetric determination of ammonia in urine. $\mathrm{J}$. Biol. Chem., 1910-11, 8, 497.

7. Havard, R. E., and Kerridge, P. T., An immediate acid change in shed blood. Biochem. J., 1929, 23, 600.

8. Peters, J. P., and Van Slyke, D. D., Quantitative Clinical Chemistry, Vol. II. Methods, pp. 282-288, Williams and Wilkins Company, Baltimore, 1932.

9. Kuttner, T., and Lichtenstein, L., Micro-colorimetric studies; estimation of phosphorus: molybdic acidstannous chloride reagent. J. Biol. Chem., 1930, 86, 671.

10. Hawk, P. B., and Bergeim, O., Practical Physiological Chemistry, Tenth Edition, pp. 875-876, P. Blakiston's Son and Co. Philadelphia, 1931.

11. Wong, S. Y., The use of persulfate in the estimation of nitrogen by Folin's direct nesslerization method. J. Biol. Chem., 1923, 55, 431.

12. Greenwald, I., Studies on metabolism in pneumonia; the excretion of "organic acid" and a method for its determination. J. Biol. Chem., 1930, 85, 447.
13. Elgart, S., and Harris, J. S., The determination of lactic acid in blood. Anal. E. Ind. Eng. Chem., 1940, 12, 758.

14. Friedemann, T. E., Cotonio, M., and Shaffer, P. A., The determination of lactac acid. J. Biol. Chem., 1927, 73, 335.

15. Van Slyke, D. D., and Palmer, W. W., Studies of acidosis; the titration of organic acids in urine. J. Biol. Chem., 1920, 41, 567.

16. Smith, A. H., and Orton, J. M., Editorial review. The nutritional and metabolic significance of certain organic acids. J. Nutrition, 1937, 13, 601.

17. Smith, A. H., Barnes, D. J., Meyer, C. E., and Kaucher, M., Metabolism of citric acid by infants. J. Nutrition, 1940, 20, 255.

18. Levine, S. Z., Marples, E., and Gordon, H. H., A defect in the metabolism of aromatic amino acids in premature infants. Science, 1939, 90, 620.

19. Levine, S. Z., Gordon, H. H., and Marples, E., A defect in the metabolism of tyrosine and phenylalanine in premature infants; spontaneous occurrence and eradication by vitamin C. J. Clin. Invest., 1941, 20, 209.

20. Medes, G., A new error of tyrosine metabolism: Tyrosinosis. The intermediary metabolism of tyrosine and phenylalanine. Biochem. J., 1932, 26, 917.

21. McCance, R. A., and Widdowson, E. M., Functional disorganization of the kidney in disease. J. Physiol., 1939, 95, 36.

22. Marples, E., and Lippard, V. W., Acid-base balance of new-born infants; consideration of the low alkaline reserve of normal new-born infants. Am. J. Dis. Child., 1932, 44, 31. 